This document replicates the text, page breaks, and page

numbering of the following journal paper:

\title{
Jean Starobinski and the Critical Gaze
}

Interdisciplinary Literary Studies, Vol. 21, No. 3, 2019.

Author: Peter Shum, University of Warwick

\begin{abstract}
This paper explores Jean Starobinski's often tacit conception of the implied author, with a view to clarifying his intellectual legacy for literary criticism. It argues that it is plausible to trace a certain strand in the intellectual genealogy of Starobinski's literary theory from the descriptive psychology of Wilhelm Dilthey to twentieth-century psychoanalysis and phenomenology. Accordingly, the question "Who is Jean Starobinski?" is formulated in a sense which seeks to move beyond the bare facticity of biographical detail, a sense that can be expected to differentiate between scholarly and purely journalistic enquiry to ask: who, exactly, is the Jean Starobinski that we encounter in his major works - works like "The Living Eye," and "Transparency and Obstruction"? It is from this vantage point that the discussion proceeds to clarify Starobinski's ambivalent relations to both Rousseau and Freud, and thereby to illuminate some of the tensions and nuances inherent in his notion of the implied author.
\end{abstract}

Keywords: Starobinski, Rousseau, Dilthey, Freud, implied author, phenomenology

\section{1: Introduction}

Jean Starobinski enquires inter alia into the nature and the person of the implied author: the implied author of Rousseau's corpus and that of Freud; of that of Voltaire; of that of Diderot, Montesquieu, Stendhal. The list goes on. More generally, he asks by implication: who is the implied author as such? How should s/he be conceived? In the case of Starobinski, then, 
we find that there is a certain recursivity to the question of his identity, since his most important "identity," under the aspect of this essay, is the one inseparable from his thought as registered in his published writings. It makes sense, then, to investigate Starobinski's conception of the implied author, not only for its intrinsic interest, but also as a way of contributing to the wider project of clarifying just who, intellectually speaking, Starobinski really is.

This will require some acquaintance with aspects of the intellectual genealogy of the Geneva School of literary criticism. Our subject is linked with the German philosopher and historian Wilhelm Dilthey (1833-1911). Dilthey was after all one of the first to formulate the notion of the life-world, and to analyze our lived experience of it. (He called this activity "descriptive psychology.") He was also an important contributor to the development of the notion of a worldview [Weltanschauung], which is supposed to constitute a coherent perspective on life, incorporating one's values, and the feelings, desires, and volitions that those values motivate. This is not to say that the roots of all important ideas underpinning the Geneva School inevitably lead back only to Dilthey. If one goes back further, one finds that it was Humboldt (1767-1835) who emphasized the centrality of one's language in shaping one's worldview, and Schleiermacher (1768-1834) may be credited with conceiving of the hermeneutic circle, the idea that the respective interpretations of a body of work and its constituent parts are interdependent. Yet it was Dilthey who first properly and most fully elaborated upon the notion of interpretation as the intersubjectively verifiable and "imaginational"1 re-enactment of the subjective experiences of another person. I would go so far as to suggest that it is in fact Dilthey who in large measure prefigures the central Geneva School conviction that what matters most in the interpretation of a literary work is the life-world of the author.

Crucially for the Geneva School, the first half of the twentieth-century saw the emergence of two quite distinct approaches to investigating mental processes, both of which turned out to be relevant to literary theory. On the one hand, there was the development of the modern disciplines of psychology and psychoanalysis, both of which had methodological aspirations to become rigorous empirical sciences. The scientific orientation of modern psychology meant that it was committed to the view that mental states and processes were ultimately to be explained in terms of properties of the natural world. On the other hand, the phenomenological movement founded by Edmund Husserl developed a critique of psychologism, according to which intentionality could only be fully understood and accounted for by 
means of an investigation into the nature of conscious experience from a firstperson perspective. Phenomenology was intended to be a foundation for the sciences (and not itself part of the sciences) by making explicit certain assumptions about the nature of conscious experience that scientific investigation already presupposed implicitly. In this sense, it provided a way of rehabilitating aspects of Dilthey's "descriptive psychology," in the face of a new wave of psychologistic empiricism. I maintain that the Geneva School derived much of its vibrancy as an intellectual force in twentieth-century literary theory by virtue of its active engagement with important developments in the fields of both psychology and phenomenology.

Starobinski is an important case in point vis-à-vis the bringing to bear of both psychology and phenomenology upon literary studies. Robert Magliola goes so far as to assert that "[Starobinski's] dependence on Husserl is widely acknowledged", and that Starobinski's essay "Poppaea's Veil" is "grounded securely in Husserlian principles."2 These claims appear slightly overstated, the former because "dependence" is too strong a characterization of Starobinski's relation to Husserl, and the latter because while "Poppaea's Veil" engages with the role of the imagination in the phenomenology of apperception, its relation to the Husserlian position on this matter is far looser than Magliola implies. Nonetheless, with recalibration, the gist of what Magliola suggests is right, since Starobinski recognizes the significance to literary studies of the phenomenological movement's fundamental interest in providing a descriptive account of phenomenal experience, and in elucidating its essential structures; in the centrality of intersubjectivity to human experience; and in the pervasive role of the imagination, in various guises, in the constitution of the life-world. To that extent, there is an undeniable debt in Starobinski's writings to Husserl, and additionally to Merleau-Ponty, who emphasizes more than Husserl the interwovenness of language and thought. It was Merleau-Ponty who made the striking claim that phenomenology and psychoanalysis are "directed toward the same latency [of lived experience],"3 a remark to which Starobinski draws attention. ${ }^{4}$ We can be sure that this observation of Merleau-Ponty's must have resonated strongly with Starobinski, who originally studied medicine, became a medical doctor, and interlaced his early academic career with postings as a physician at various Swiss clinics, including a psychiatric hospital in Lausanne, before turning full-time to academic life in 1958 at the age of thirty-eight. It is therefore not surprising that Starobinski's writing is often imbued with the tincture of the psychoanalyst-analysand relation. 
I want to suggest that Starobinski's project cannot be properly understood without an adequate grasp of his relation to Freud, which takes us deep into Starobinski's method for the apperception of the implied author of a text. I shall begin by elaborating further on the bearing of Freudian psychoanalysis on Starobinski's approach to literary criticism, before proceeding to discuss at greater length Starobinski's encounter with Rousseau. I adopt this order of topics because Starobinski, on my reading at least, enlists the assistance of Freud in making sense of Rousseau's psychological theory, for instance via the concepts of narcissism, and the compensatory theory of art, and in making sense of Rousseau himself, for instance, via the concepts of neurosis and paranoia. In order to understand Starobinski's reading of Rousseau, we need to understand certain aspects of Starobinski's reading of Freud. Taken together, my hope is that the conjunction of these enquiries in this article will go some way toward explaining why Starobinski has an important place among the so-called Geneva School "critics of consciousness."

\section{2: Starobinski and Freud}

Starobinski understands artistic creativity to be the special ability of giving a voice to something which cannot speak on its own, the deep stratum of consciousness that phenomenologists call lived experience. Poets reveal by means of rhetoric the life of the emotions. They are, Starobinski believes, the "mouth of shadow." art, Starobinski consistently emphasizes one: to describe, explore, and, in a very particular sense, satisfy one's own desires. The result in personal terms for the artist can be profound. One finds that one has not only found a way of reckoning with the frustrations of the past, but has, through the power of the imagination, begun to escape them and germinate a different future. The upshot is that we transcend and create ourselves by seeking in artistic creativity what we lack.

A signature Starobinskian insight is that this structure of the expression of desire has defining implications for art criticism. The literary text may disguise and dissimulate the author's desire, but it also reveals it. Starobinski's conviction is that the author's real-world desires do ineluctably reappear in the work in some configuration. They may not be directly perceptible in the work's manifest content, but they may be discerned, apperceived, or otherwise inferred at the level of a certain latent content, a latent content [continued overleaf] 
that is not in the end obscured behind the text like a face behind a mask, but ultimately understood to be engrained in the text itself. According to the Starobinskian account of the phenomenology of critical literary experience, over time one becomes aware as a reader of a complex organic and personal presence that has structure and organization, desiderata and motivations. The literary work in its totality accordingly comes to be apprehended by the attentive critic as a plexus of revealed intentions.

This brings us very close to much that is central to Starobinski's affinity with Freud. Starobinski readily acknowledges his enormous debt to psychoanalysis, and admires Freud's exegesis of various literary works. ${ }^{6}$ The similarities between the respective tasks of the psychoanalyst and the critic run deeper than simply the imposition of the presumption of intelligibility on their analysands. To be sure, both the psychoanalyst and the literary critic are engaged in a project of interpretation. They both attend carefully in the first instance to what is manifestly given, with a view to discerning what remains hidden or latent. They both seek to expose desire lying below the surface. Yet psychoanalysts are often inclined, furthermore, to view their patients precisely in literary terms. The patient him/herself becomes an expressly literary object of study when encouraged by the analyst to produce life narratives and free associations, and to describe the content of his or her dreams. $^{7}$

Starobinski, when first confronted with a literary work, seeks the same kind of vigilant neutrality that an analyst directs toward a new patient. ${ }^{8}$ As a critic, one must in this sense simply take in what is given before underlying themes and features begin to take shape. Only after primordial impressions have been made may one proceed, quite possibly by employing other techniques originating from the field of psychoanalysis, in order to bring to light key relations between ostensibly aleatory phenomena.

Yet Starobinski's incorporation of Freudian thought is not without its tensions. Certain dissonances are traceable to a fundamental disagreement over the status of psychoanalysis as a discipline. Freud believed that his project of investigating mental experiences and the unconscious belonged to the domain of science. Yet Starobinski observes that the experiences of patients are always unique; that the patients' experiences of their symptoms are affective; and that psychoanalysis does not employ experimentation or measurement in the normal scientific sense. ${ }^{9}$ If the phenomena of psychoanalysis are affective, it is reasonable to enquire into the implications of this fact for the language of psychoanalysis. Freud himself registers an awareness that terms like "narcissistic" and "oedipal" are approximate and 
metaphorical. Yet, crucially, he also expresses a desire that such approximations should eventually be replaced with the language of hard sciences like physiology and biochemistry. Starobinski's difference with Freud stems from the view that the hope for such a discursive development within the discipline of psychoanalysis is fundamentally misconceived.

Secondly, Starobinski observes that Freud's scientific conception of psychoanalysis places constraints on the manner in which Freud seeks to apply psychoanalysis to the study of art. In particular, Starobinski is concerned that Freud's engagement with art is oriented toward a reductive analysis. ${ }^{10}$ Freud's reductive tendency is exemplified in his compensatory theory of art, according to which artistic creativity amounts to a substitution by the imagination for an object that the artist desires but cannot obtain. Thus, artistic creativity comes to be understood as an attempt by the artist to repair an unhappy relationship with the world. Starobinski is concerned about the adequacy of Freud's compensatory theory of art, on the grounds that it becomes facile when it tries to explain a literary work solely in terms of the author's life up until the time of writing it. The compensatory theory seems to overlook the fact that the act of creating a literary work is also an important and formative part of the author's life. The life cannot be said to determine the work, if the work is itself part of the life. ${ }^{11}$

To envisage psychoanalysis as a scientific discipline through and through would be to commit oneself toward an eradication of the imprecisions of literary language in psychoanalytic discourse. Starobinski attributes to Freud the assumption that to fail to do so could leave the discipline vulnerable to a similar kind of critique as that expressed in the compensatory theory of art. This leads Starobinski to the view that in Freud's writings there is a kind of repression going on: a repression of the literary. Starobinski believes that Freud represses the idea that there should be a literary dimension proper to the field of psychoanalysis itself. ${ }^{12}$

Is Starobinski trying to out-Freud Freud? Arguably so, and the corollary to Starobinski's repression hypothesis is not difficult to anticipate. A return of the repressed is what Starobinski attempts to locate in the Freudian corpus. The key to this discovery lies in the recognition of the fact that many of the mental phenomena that Freud describes are affective in nature. The language of psychoanalysis is itself figurative and metaphorical in order to cope with the demands of describing affectivity. Starobinski points out, for instance, that Freud's rhetoric often plays with light and dark: the contrast between what appears and what is hidden; that Freud's syntax and vocabulary often have a mythopoetical element; that Freud's account of the economy of libidinal energy 
is allegorical. ${ }^{13}$ In short, Starobinski argues that the nature of the objects under Freud's scrutiny demand that psychoanalysis should be trapped in metaphor, and compels Freud to borrow and incorporate concepts from literary criticism.

At one level, Starobinski sees value in adopting the Freudian attitude. Much of Starobinski's literary criticism seems to be imbued with, in one way or another, the tincture of the analyst-analysand relation. At a different level, however, in the context of this alignment, an important critique of Freud is also developed. It is a critique which has implications for the interdisciplinary relation between psychoanalysis and literary criticism, and which thereby helps us to re-imagine, beyond what Freud ever envisaged, the status and possible future for psychoanalysis as a discipline.

\section{3: Starobinski and Rousseau}

Is Starobinski's relation to Rousseau similarly dialectical? The respective and notably polymathic interests of Starobinski and Rousseau coincide perhaps most strongly around questions of otherness, and the intersubjective significance of literature. Starobinski's engagement with Rousseau naturally has its historical and philosophical dimensions, but beyond these the powerful gaze to which Starobinski subjects Rousseau is also infused with a selfreflexive subtext of literary theoretical questions. Rousseau functions ultimately not only as the object of study, but also as a case study in literary criticism, from which it is hoped that wider theoretical conclusions may be drawn. Criticism, as Starobinski suggests in his essay The Critical Relation, is ultimately obliged to look beyond the textual object and its concomitant world, towards a "generalisation of its discoveries," toward "a theory (in the sense of theoria, intellectual contemplation) of literature." 14

Meta-critical and theoretical questions are therefore seldom absent from the horizon of Starobinski's thought. What are the ends of criticism? In what sense can the text of Rousseau's work be said to be revelatory of Rousseau himself? More generally, what responsible function can the term "author" credibly take on in literary theoretical discourse? In these senses, in the broad sweep of Rousseau's thought, and in particular in Rousseau's own reflections upon the nature of literature, the ends it might serve, and his envisaged directions for its potential transformation, Starobinski finds a fruitful way into some central theoretical and meta-critical questions relating to the very possibility of literary self-disclosure, the role of the critical imagination, and the nature of interpretation. 
The striking, indeed revolutionary, feature of Rousseau's literary ambitions, and his ambitions for literature itself, is the way in which he sweeps aside the notion of literary language as a common property or tool for the production of meaning that is in some substantive sense distinct from the author's own subjectivity. Instead, the work is understood to somehow (Rousseau's failure to adequately explicate this is ultimately significant) embody the author's very being. As Starobinski puts it, Rousseau "was the first to experience the dangerous compact between ego and language, the "new alliance" in which man makes himself the word." ${ }^{\text {"15 }}$ It is this theoretical paradigm shift, entailing an authorial re-appropriation and re-assimilation of language, which leads Starobinski to claim that Rousseau "truly invented a new attitude, which became that of modern literature."16

Given such extraordinary stature accorded to Rousseau, specifically as a literary thinker, the paradox of Starobinski's engagement with Rousseau lies in the consistent emphasis Starobinski places upon the significant inadequacies in Rousseau's theoretical understanding of literature. This is indeed, I would suggest, the crucial dialectic informing Starobinski's relation to Rousseau. Starobinski's insight into Rousseau's aspirations for literature is that, while they seem to provide prima facie grounds for dismissing Rousseau as (in a certain disparaging sense) a sentimental Romantic, the very fault-lines in Rousseau's implicit manifesto for literature themselves intimate and open up radically new and important literary theoretical and meta-critical questions. Let us look more closely at what, in Starobinski's view, seems to go wrong in Rousseau's account.

Rousseau's literary project is bound up with a quest for selfknowledge. Self-knowledge would seem to be a logical pre-requisite for faithful self-portraiture, which is the explicitly stated aim of his Confessions. Yet for Rousseau, self-knowledge is not only logically prior to such unflinching autobiographical literary production, for as we shall see, selfknowledge itself is attained precisely in and through such literary endeavor. The attainment of new forms of self-knowledge comes to be understood to be part of the subjective significance of being an author.

In the interests of self-knowledge, Rousseau intends in writing his Confessions to both re-live past experiences and work at other times as a detached self-observer. As Starobinski puts it, Rousseau assigns himself a double duty of "complete unity and total fission." ${ }^{17}$ Rousseau's view that selfknowledge stems from both feeling and detachment echoes his ambivalent stance toward reflection. To be sure, reflection in the first instance is held to fracture the idyllic self-presence for which Rousseau longs. 
Yet on occasion Rousseau also concedes that a sustained regression to the primitive pre-reflective state is impossible. Instead, the unavoidable remedy lies in a painstaking and progressive transformation of man through ongoing reason and reflection. Reflection, for Rousseau, turns out to be both poison and cure.

Rousseau's proposal for a transparency of expression is motivated by what Starobinski calls a "soulful imperative,"18 an impulse to disclose with perspicuity one's deepest affective states. Let us consider in more detail Rousseau's idea of a literary work being in some sense adequate to the author's phenomenal being. Formulated thus, without reference to a reader as such, it amounts to a view that Starobinski is broadly prepared to sustain. Starobinski explicates it as a particular form of artistic narcissism. It finds an analogy in the myth of Pygmalion, who desired his own artwork (an ivory statue) to such a degree that Aphrodite decided to answer his prayer and make it come to life. Narcissism of this kind involves a double movement which obviates the need for the kind of straightforward self-reflection provided by a mirror. One initially alienates oneself in the production of the work, only to seek self-communion precisely through engagement with the work. Far from disparaging such narcissism, Starobinski stresses its deeply demanding and creative nature. Perhaps most importantly, the artistic desire involved is bound up with the imagination. For Rousseau, the imagination is the setting not only for a kind of curiously perfected yet introverted intersubjectivity, but also for an idyllic self-love and self-presence. Pygmalion adores himself in what he has made.

The suggestion here is that while relations with others may seem only to disappoint in comparison with fantasy, an imagined communion with the "Other" of one's own artwork offers the catharsis and satisfaction of a perfect interaction. It is in this movement that affective adequation is apprehended by the artist. The artwork compensates the artist for the disappointments of life, for unrequited desire. In communing with his desire, Rousseau attains the kind of primitive happiness he craves, in which he is sufficient unto himself.

I suspect that what is right about this idea is that it captures the movement of an entirely plausible account of authentic poetic creation. According to this account, the poet in his or her most private moments is possessed of a pure motivation not so much to communicate as simply to express - to externalise, even expurgate - something that lies within. Naturally, the poet has a good sense of when such expression has been accomplished, of when the job is done, so to speak. In this case, questions of communication, of 
being understood, are in an important sense secondary, or even immaterial for the artist. As Starobinski suggests, Rousseau was arguably among the first to seriously give primacy to the expressive function of literary language. But the difficulty with Rousseau's conception of the transparency of expression lies in its Janus-like quality of looking both back to the author's interiority and forward to the reader as such. Rousseau's self-expression always seems to have not only an accusative but a dative, an anonymous "Other" to whom Rousseau imagines he is disclosing himself. This conception of transparency of the text for the reader holds out the promise of a primordial sympathy between reader and author of the kind considered earlier, and, in Rousseau's case, thereby overcoming his sense of social alienation. Thus, Rousseau's conception of literary expression ultimately turns out to be a conflation of self-expression and self-disclosure.

As Starobinski points out, this turns out to be deeply problematic, both in literary theoretical terms, and in Rousseau's personal experience as a writer. The author may attain a kind of privileged self-communion in the work, but what Rousseau seems to overlook is that for any other reader of the work, the experience must necessarily be quite different. For readers other than the author, the encounter with a literary work is, as Starobinski puts it, "predicated upon loss of the object and its replacement (I do not say representation) by words." 19 Literature is conditioned by the absence and inaccessibility of the originating primordial experience. What Starobinski calls "the purity of immediate sentiment," 20 far from being preserved for others, is precisely what is lost, the very moment the ink leaves the writer's pen. And authors become obliged, too, to take existential responsibility for the meanings they choose to see in their own work. But for Rousseau, the possibility of a proliferation of possible meanings leads only to anxiety about hostile and malicious interpretations. His later works, such as Confessions, betray a nervous cycle of correction and clarification.

Rousseau's apparent obsessional neurosis about the possibility of his writings being misunderstood is suggestive (to Freudian eyes at least) that he may have developed for himself the apprehension, unconscious or otherwise, that there was something inherently misguided about his aspirations for the transparency of literature. Notwithstanding any doubts he may have had, however, Rousseau also preferred on occasion to disparage his own writing abilities and perpetuate his literary idealism. But Starobinski's scrutiny of Rousseau's project compels us now to confront the underlying theoretical problem that Rousseau unwittingly brings to light: if the very conception of literature as some kind of window onto the human heart [continued overleaf] 
begins to unravel before Rousseau's very eyes, to what extent does it make sense at all to configure the encounter with a literary work in intersubjective terms?

Starobinski is certainly alive to the seductions and pitfalls, epistemic and moral, of pretensions of being able to divine a soul in the transient play of appearances. According to Starobinski, the deepest intellectual concerns of The Living Eye [L'Oeil Vivant], published in 1961, were already germinating in his mind some twenty years earlier amidst wartime anxiety surrounding the captivating power of charismatic leaders. What seems to have chilled the young Starobinski was the realization that the charisma of such individuals "stemmed essentially from their knowing how to make use of a certain kind of mask." ${ }^{21}$ For Starobinski, the perils of being seduced by appearances are bound up with a more general problematic of the desirous gaze. And he takes seriously the implicit insights and admonitions of classical myth. Poppaea's lovers come to grief because of their impetuous desire to see behind her veil. ${ }^{22}$ For the critic who desires to see too much, the risks are also serious. To fail to retain some distance from the text is to risk losing one's bearings in a manner which parallels the way in which Rousseau's persistent desire to see into others' hearts most often ends badly for him, in humiliation, confusion, or (in the end) paranoia. In attempting to see what cannot be seen, one is prone to fill in the void with a narcissistic projection. In Rousseau's case, a sense of personal guilt, apparently instilled during his puritanical upbringing, was not infrequently transformed into the presumption of the silent censure of others, the mirage of the hostile gaze.

In this context, Starobinski accords some validity to Paul Valéry's view that, at least in the normal course of events, and despite polite protestations to the contrary, we never do quite see with perspicuity into other people's affective lives. There is always an essential moment of ambiguity, a kind of truncation in empathic precision. Valéry traces the undecidability of foreign affectivity to a dialectical moment of signitive disguise that he considers to be constitutive of all human relations. "Human relations are based on ciphers," Valéry informs us; "To decipher is to become confused."23 For Starobinski, part of the significance of this Valérean line of thought lies in the sense that, even in the very act of revealing oneself, something is always held back, obscured, or deferred.

Yet this hardly confounds the case for an intersubjective approach to literature. To the extent that empathy does take place in human relations, should we not at least take seriously the possibility of a literary analogue? Starobinski stands by the view that to the extent that a literary work implies 
thought at all, such thought cannot but be correlated with a consciousness employing the available linguistic resources of the times. Starobinski's own dialectical solution to the problem of literary intersubjectivity centers on his conception of a work's implied author. I shall devote most of the remainder of this essay to examining this idea more closely.

\section{4: Starobinski’s Critical Gaze}

Starobinski's engagement with Rousseau has put Rousseau's literary ideals, and his manifesto for the transparency of literature, under quite serious pressure. Perhaps it is at junctures such as this that the many advantages of the critical approaches of the formalists, structuralists, and textualists become most apparent. In restricting attention to objectively observable features of the work, and to the life of the text itself, difficulties connected with the urge to see a hidden source or origin beyond what is manifestly given are systematically avoided. Starobinski himself finds merit in, and draws upon the insights of, structuralism. ${ }^{24}$ Yet one of the dialectical subtleties of Starobinski's approach to the study of literature lies in the importance, indeed necessity, that he attaches to traditional philological rigor in tracking down, to the maximum scholarly extent possible, the nature of a given text's originary historico-linguistic context. To be sure, for Starobinski, cultural context and supposed Zeitgeist are not in themselves wholly adequate explanations of the literary work. The greatest authors not only subsist within their cultural environment, but kick against it, innovating and invigorating the very womb from which they are born. Yet this very individuality can only become fully delineable and intelligible against its contemporary cultural backdrop. Starobinski studies Rousseau in his socio-historical context precisely to illuminate Rousseau's radical differentiation and innovation. And Starobinski's point of departure from the formalists lies in the view that the literary text cannot ultimately be properly distilled or withdrawn from the passage of history. For this reason, he does not equivocate on the point that a diligent undertaking of the usual philological groundwork - the determination of "precise definitions of words in their historical context," for example, and "establishing scrupulously accurate texts" ${ }^{\prime 25}$ in the first place-is quite simply a prerequisite for any subsequent critical work, regardless of interpretive brilliance.

Even so, Starobinski's methodological interest in literary origins should not be interpreted as evidence of a literary theoretical commitment, at least

[continued overleaf] 
in terms of the most crucial and distinctive aspects of his theoretical position, to a conception of "author" as necessarily absented and distantiated across the divide of historical time. Starobinski's theoretical understanding of literature ultimately moves well beyond the terms and ambit of a purely philological discourse. Nonetheless, in Blindness and Insight, Paul de Man claims that in his treatment of Rousseau, Starobinski is attempting to intuit truths about the historical Rousseau, truths that lie beyond the ostensible meaning of what Rousseau actually wrote. ${ }^{26}$ In the preface to The Living Eye, however, Starobinski, while admitting that his critical perspective may require some supplementary clarification, convincingly answers de Man's charge by pointing out that Rousseau himself urges his readers not to read him at face value. Starobinski insists that his critical interest never alters its focus from the Rousseau as author implicit across the entirety of Rousseau's work. For Starobinski, the literary text is not conceived as a mask behind which a pregiven author is a priori condemned to concealment, but instead as precisely a privileged disclosure of a particular and distinctive conscious interiority.

For Starobinski, the idea that a literary work should be correlated with an individual consciousness is not an isolated critical theme or mere phenomenological detail, but instead goes to the nucleus of his conception of what literature turns out to be, at least in its greatest and most significant manifestations. To adumbrate such individuality, it is not sufficient for a work to simply employ a given language, to operate it according to its grammatical and syntactical requirements, and according to one's referential intentions, that is, to master it as one masters a bicycle to accomplish a specified journey, no matter how original or pioneering that journey may be. The literary work is distinguished from other instances of language usage by the fact that it changes the language in some way, and makes it its own. Literature ruptures the determinacy of language, in the sense that it is both conditioned by and conditions its language. The autonomy of literature gives it, in a very peculiar sense, the power to change the course of history: it can alter the shapes of consciousness in a dialectical action of compliance with, and subversion of, its language. As Starobinski sees it, the essential tension of literature is that it is both a "celebration" and a "profanation" of language. ${ }^{27}$ It is, in particular, this aspect of profanation which enables the correlation of a text with an individuated and distinctive consciousness, and informs Starobinski's fundamental intuition that literature is "intimately associated with a personal way of being in the world". ${ }^{28}$ 
The "profanation" of language of which Starobinski speaks can be understood in multiple ways. In one sense, at work here is an image of trauma and transgression. Writers, though existing within, or in relation to, a prevalent culture, make their way out of the temple of the cultural Logos, of linguistic and spoken conformity, toward a more marginal, semi-detached vantage point. From belonging within, the writer withdraws into a kind of parasitic ambivalence, if not overt hostility. Starobinski observes that the outstanding works of modern literature tend to relate to the world by rejecting it in some way. The opposition to culture comes to be reflected in the violation of its literary and linguistic norms. At some level (precisely which, the critic must judge) the work remains internally consistent, yet stubbornly opposed to its outside. It falls to the critic to uncover the signs of aberrance and destructuring manifestly or latently operating within the work. ${ }^{29}$

Yet Starobinski also recognizes that literature's profanation of language is not always obviously traumatic. There is a more emollient way in which literature announces its cultural differentiation and individuation, and it involves bending and deforming language out of its customary shapes and contours. At this level, the question of hostile transgression becomes less prominent, and language's profanation becomes, too, its celebration. The writer may have left the temple, but may also turn outside to face it, to stand before it. While the style of a work may break or vitiate its host language, it may equally bend it and place it under the torsions of a personal rhetoric. Either way, the notion of literary style, for Starobinski, has now become intimately, even inseparably, associated with existential style. Such "style" can push expressive capacity and suppleness to its limits. Style as such has now become something more substantive than a vague reference to a work's way with words. Style is now not only surface but somehow contiguous with existential reality, not only artistic appearance but an opening onto authorial being.

In this respect, Starobinski believes that, for all of Rousseau's excesses, there is still something to be learnt from Rousseau's ambitions for style: Rousseau understands style's simultaneously subversive and authentic moments. Rousseau comes to the view that the nature of style, or at least of the kind of style that his own autobiographical endeavours require, must be far more radical than merely the superficial, expedient, or even cynical employment of rhetorical technique and literary artifice. The allegiance of style lies not with accepted fashions or mannerisms, with the prevalent cultural grooves of expression (no matter how intricate or sophisticated 
they may have become) made familiar in the daily traffic of social encounters, but with the impulses, motivations, and directions of the individual's conscious interiority. The production of an authentic style amounts to the invention of a new language, or what one might call the creation of a personal dictionary. As Rousseau pledges in Confessions,

I will always have whatever style comes to me; I shall change it without scruple according to my mood; I shall say each thing as I feel it, as I see it, without straining for effect, without embarrassment, and without worrying about the mixture of colours. By surrendering to the impression received and to the sentiment of the moment, I shall paint the state of my soul twice over, at the moment the event occurred and at the moment I wrote it down. ${ }^{30}$

Even as Rousseau elaborates his philosophy of style, the cracks in his position become more apparent. While his literary aim is clearly fixed (or fixated) on self-immediacy and self-transparency, he finds himself driven to a signitive metaphor to capture the operations of his authorial processes: an image of painting. The difficulty here is that representation is somehow being conflated with presentation. A painting of Rousseau does not render present Rousseau, except in the most hyperbolic of views. If it did, one would perceive Rousseau, not a painting of him. Depending upon the skills of the artist, Rousseau may be said to be depicted, but in depiction, qua depiction, the transparency of immediacy is ineluctably lost.

Starobinski intimates precisely this problem when summarizing Rousseau's understanding of the function of style: "Style [for Rousseau] points infallibly to the author's inward truth." ${ }^{, 31}$ It would seem that the aporia in Rousseau's thought has now been relayed into Starobinski's paraphrase, in which "painting" has become "pointing," and that Starobinski's very effort to convey Rousseau's view coherently results in the dubious idea of an infallible pointing. But pointing, like painting, necessarily implies distance, and distance surely precludes infallibility.

I alluded earlier to some of the alternative theoretical approaches to literature which could be said to bypass the troubling question of intersubjectivity. The siren call of scepticism would seem to offer the modern critic a comfortable way out, a resigned, even quietly relieved, retreat into the dispassionate impersonal analyses of structure, form, and text. The sceptical escape route even seems attuned, on the face of it, to the very ethos of detached critical discourse. To simply look carefully at a text, instead of 
curiously, even desirously, into it, is to remain discretely isolated from the difficult involvements of empathy and feeling, and, in short, the personal encounter.

The originality of Starobinski's ultimate critical response to Rousseau lies in the fact that he does not straightforwardly discard the spirit of Rousseau's intersubjective aspirations as some kind of hopeless artifact of a discredited form of Romantic idealism. The Starobinskian insight into Rousseau is to observe just how close Rousseau actually comes to a cogent view of the intersubjectivity of literature. Rousseau is fundamentally right, in Starobinski's view, to propose and pursue the idea that questions of intersubjectivity go to the heart of what it is to be a writer, and of what it is, in turn, to encounter as a reader a work of literature. Rousseau loves truth, and values highly the love of truth. But he is dissatisfied with reason, and suspicious of self-conscious reflection. He sees truth as bound up with the passions, and configures intersubjectivity in terms of a disclosure of the passionate truth of the Other. In the sense of wanting to preempt a topology of the self as comprising an inside and an outside, Rousseau has aspirations toward a primordial unity with others, and understands, in his own way, literature to be a passage toward the authentic disclosure of the truths of phenomenal being.

Rousseau's difficulties, however, at both a theoretical and a personal level, seem to be connected to an inadequate grasp of the relation between appearance and reality in the context of encountering the Other. Rousseau sets out in his literary work, and often too in the encounters described in his Confessions, to somehow circumvent external appearances. He desires to bare his own heart, and to see directly into other people's. Yet his literary dissatisfactions, and his social disconnections, suggest that his project has ultimately turned out to be even more complicated than he had initially anticipated. Starobinski's reading of Rousseau interprets this not so much a failure, but as a discovery. Rousseau has run up against a structural problematic underlying the encounter with otherness, which Starobinski construes in terms of a dialectic of transparency and obstruction.

It is a conundrum that Starobinski not only draws attention to, but also wants to begin to solve for himself. Starobinski has the edge over Rousseau in this regard, since Starobinski has at his disposal certain discoveries and resources belonging to disciplines that Rousseau could scarcely have foreseen or imagined. One of these disciplines is psychoanalysis, the beam of which Starobinski attempts to direct not only at Rousseau himself, and his predicament, but more generally into what he, Starobinski, regards as 
core issues in literary and critical theory. One way in which Starobinski accomplishes this is by bringing to light certain blind-spots in Romantic conceptions of literary self-expression, and of the intersubjective significance of literature. One of the Romantic aporia that concerns Starobinski is the mistaken conflation of self-expression with self-disclosure, a conflation that neglects the idea that something may always be deferred in the empathic encounter with the Other. The necessary possibility of a truncation in empathic precision entails that the guarantee of what Starobinski calls the "purity of immediate sentiment" will be lost for even the most careful of readers, other than, perhaps, the original author him/herself. Possible meanings will ramify and proliferate for different readers. And an hermeneutic jeopardy opens up for critics, such that in attempting to see what cannot be seen, one may be prone to fill in the void with a narcissistic projection.

Psychoanalysis aside, Starobinski also makes judicious use of the insights to be found in twentieth-century phenomenology. It would be too restrictive to try to cast Starobinski as simply an Husserlian literary theorist. This is so, not only due to the Freudian connection, but because his thought is also influenced, in ways whose adequate exploration lies beyond the remit of this article, by Merleau-Ponty and Sartre. We may say with certainty that Starobinski's conception of the encounter with the personality of the implied author of a literary work is profoundly influenced by the way in which the phenomenological movement that Husserl founded became deeply interested in certain forms of co-givenness involving the structure of the constitution of a phenomenal unity that cannot be rendered intelligible by appealing to notions of signification or indication, and in the phenomenological discovery that under certain conditions, as Edith Stein paraphrases Johannes Volkelt, " $[\mathrm{t}]$ he experiences we comprehend in expressive appearances are fused [verschmolzen] with the phenomena of expression. ${ }^{\circ 2}$ The distinctiveness of Starobinski's conception of the implied author lies in the way he draws upon the phenomenological tradition in order to find a way of upholding something of the Romantic conviction in the centrality of feeling and empathy in literary experience. Yet in doing so, Starobinski delineates aspects of the interpersonal encounter, and of the relation between appearance and reality, that various Romantics (I include Rousseau here) preferred to ignore, but which turn out, on the Husserlian account at least, to be constitutive of intersubjectivity itself. It is in this regard that Starobinski's account of the implied author turns out to link the purely phenomenological exploration of intersubjectivity and 
the imagination undertaken by thinkers like Husserl, Stein, and MerleauPonty, with literary theoretical questions pertaining to the apperception of a personality sunken within an extended text or collection of texts. The implied author is textually inherent.

\section{5: Conclusion}

A more lengthy disquisition on Starobinski's thought would help to bring out in greater detail the ways in which he denies neither that objective textual analysis is important to literary criticism, nor that the literary work always remains essentially open to multiple readings, and that critics ultimately find themselves to be existentially implicated and entangled in the forces at work in their own interpretations. Yet perhaps the most theoretically decisive aspect of his thought, the commitment which, on my reading at least, governs his fundamental understanding of criticism, is the view that the literary work itself, in conjunction with (yet moving beyond) purely historical and philological enquiry, has the capacity to grant readers an intersubjectively privileged insight into the intentionality of the Other, that is, that the work possesses and opens onto an inherent authorial consciousness.

This conception of the inherence of what is Other leads Starobinski to regard the interiority of the inherent author as a kind of latency within the work. The Other's experience, precisely in being that of an Other, is not, to the reader's eye and mind, primordially accessible and apprehensible in the manner in which the textual surface and its manifest semantic value could be said to be. The Other is present within the work, neither manifest at the surface nor hermetically sealed behind the symbols of the text. Instead, the Other is accessible via the text, susceptible to what Starobinski calls a "greater penetration" into the work, toward its "second meaning." 33 We are dealing here with neither an encryption nor a straightforward occlusion. The critic's work is not at root to be understood as a project of deciphering, accomplished with the hypothesizing guile common to allegorical or psychoanalytical interpretations, but rather as a much more direct seeing into the work, an apperceptual penetration. I take this to be the "optics" of Starobinski's Oeil Vivant.

The textual Other is never disjoint from its textual appearance because its principal presenting aspect is that of literary style, the expression of 
authorial individuality in the "profanation" of language. For this reason, the search for what is deepest in a work often returns to what is formally and semantically relatively near to the surface of the text. Starobinski intimates this deeply phenomenological idea of a transcending of the appearance/reality opposition in the following way:

Frequently the search for what is most remote leads to what is nearest at hand: to what was obvious at first glance, the forms and rhythms that seemed merely to hold the promise of a secret message. After a long detour we come back to the words themselves, where meaning chooses to reside, and that gleaming mysterious treasure we had felt compelled to seek in a "deeper dimension." 34

Literary façade and underlying being are ultimately fused into coherence: there can be no circumvention of the text. And in the literary as in the purely phenomenological domain, Starobinski suggests, we find the ontological force of the appearance/reality dichotomy to have been all but neutralized.

My claim is that an important part of Jean Starobinski's intellectual significance stems from his ability to contemplate the critical gaze through the prisms of two of modernity's most significant and influential "mind sciences": psychoanalysis and phenomenology. His project is directed not so much toward the development of a manifesto for the future of literature, as a clarification and a disclosure of what great literary works very often (I do not say always) truly are, in the light of important developments in the social sciences and the humanities. He has other prisms in his repertoire, notably that of existentialism.

The trajectory of Starobinski's thought has now taken us from a strictly psychophysical conception of "author" to one belonging to pure consciousness. The concept of author has been transposed from embeddedness within history into the domain of the imagination. For this reason, Starobinski understands the intersubjective latency of the text to be "the vaster life or transfigured death inherent in it." Starobinski refers is that of the original living intentions of the historical author, a necessary death, promised and predicted in the undoing of Rousseau's fated hopes for literary self-transparency. Yet the "author's lived intentions" as such find a sense in which they can meaningfully survive, but only in a "transfigured" and nonprimordial form, buried yet readable within the permanence of a text. 
Peter Shum is Associate Fellow of the Higher Education Academy in the UK, and has taught undergraduate modules in logic, philosophy of language, history of modern philosophy, and aesthetics. He has research interests in phenomenology, literary theory, aesthetics, and ethics. He is an alumnus of the University of Warwick, where he also taught in the philosophy department.

\section{Notes}

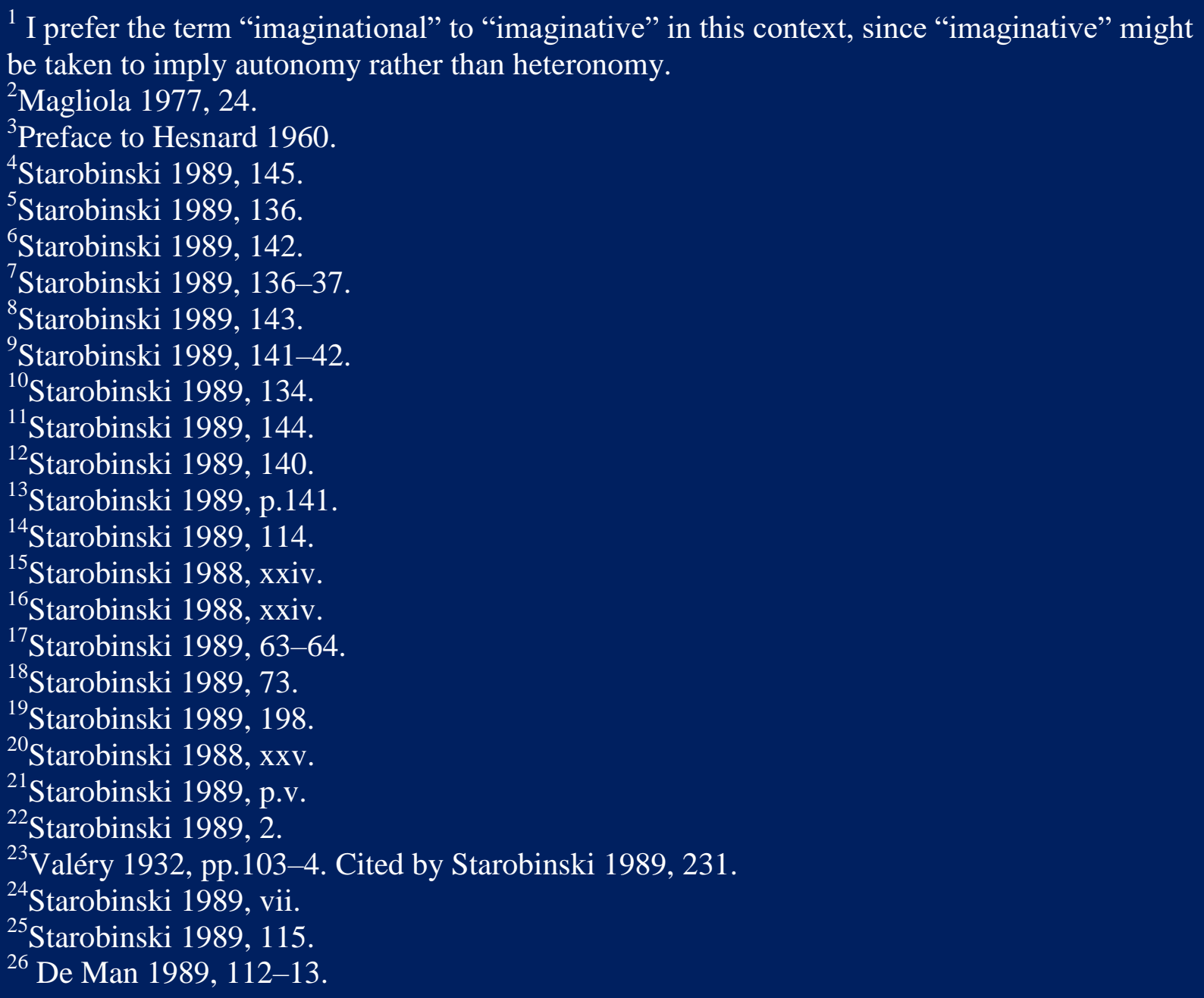


${ }^{27}$ Starobinski 1989, 116.

${ }^{28}$ Starobinski 1989, 215.

${ }^{29}$ Starobinski 1989, 120.

${ }^{30}$ Rousseau 1959, Book I, 1153-54. Cited by Starobinski 1989, 179.

${ }^{31}$ Starobinski 1989, 178-79. Emphasis mine.

${ }^{32}$ Stein 1989, 127 n102.

${ }^{33}$ Starobinski 1989, 11.

${ }^{34}$ Starobinski 1989, 12.

${ }^{35}$ Starobinski 1989, 12.

\section{Works Cited}

De Man, P. 1989.Blindness and Insight: Essays in the Rhetoric of Contemporary Criticism.London: Routledge.

Hesnard, A. 1960.L'Oeuvre de Freud et son importance pour le monde moderne. Paris: Payot.

Magliola, R.R. 1977.Phenomenology and Literature.Fort Wayne, IN: Purdue University Press.

Rousseau, J-J. 1924.Correspondance générale de J.-J. Rousseau. 20 Vols.Edited by T. Dufour.Paris: Armand Colin.

—.1959-60.Oeuvres Complètes. 4 Vols.Edited by B. Gagnebin and M. Raymond.Paris: Gallimard.Ébauches des Confessions, Book I, p.1164.

Starobinski, J. 1988.Jean-Jacques Rousseau:Transparency and Obstruction.Translated by A. Goldhammer.Chicago: University of Chicago Press.

Starobinski, J. 1989.The Living Eye. Translated by A. Goldhammer.Cambridge, MA: Harvard University Press.

Stein, E. 1989.On the Problem of Empathy. Translated by W. Stein.Washington, DC: ICS Publications).

Valéry, P. 1932.Choses tues.Paris: Gallimard. 